\title{
Spontaneous remission of the mandibular nerve paresthesia: a case report
}

\section{Remissão espontânea da parestesia do nervo alveolar inferior: relato de caso Remisión espontánea de la parestesia del nervio alveolar inferior: reporte de caso}

Ronald Jefferson MARTINS

Naiana de Melo BELILA

Mayumi Domingues KATO

Cléa Adas Saliba GARBIN

Department of Children and Social Dentistry, Araçatuba Dental School, UNESP

Universidade Estadual Paulista, 16015.050 Araçatuba, SP, Brazil

\begin{abstract}
Introduction: Paresthesia is usually characterized by a transient loss of sensitivity in the area covered by the affected nerve. Different causes may lead to this occurrence; among them, the injury of nerve structures during the extraction of third molars The sensitivity recovery depends on the regeneration of the nerve fibers, and in most cases it occurs spontaneously. In some situations, there is a need for a more invasive and expensive treatments to the patient. Objective: The aim of this study was to evaluate the spontaneous remission of the inferior alveolar nerve paresthesia. Case report: We studied a 34 year-old patient white, male, which presented paresthesia of the inferior alveolar nerve after extraction of the lower right third molar. We chose to wait for the spontaneous return of the sensitivity, which occurred between the first and second postoperative month. Conclusion: The complete recovery of the sensitivity does not occur in all cases, even with the recommended treatments. So the best way to deal with paresthesia is prevention, where the dentist must perform the correct diagnosis with the aid of the necessary additional tests; besides having skill and dexterity in handling the instruments, so that the surgery would be performed safely and without any complications for the patient.
\end{abstract}

Descriptors: Paresthesia; Remission, Spontaneous; Mandibular Nerve.

\section{Resumo}

Introdução: A parestesia caracteriza-se normalmente pela perda transitória da sensibilidade na área abrangida pelo nervo afetado. Diferentes causas podem levar a esta ocorrência; entre elas, a lesão de estruturas nervosas durante a exodontia de terceiros molares. O retorno da sensibilidade dependerá da regeneração das fibras nervosas, sendo que na maioria dos casos ocorre espontaneamente. Em alguns situações, há necessidade de tratamentos mais invasivos e dispendiosos para o paciente. Objetivo: O objetivo do estudo foi avaliar a remissão espontânea da parestesia do nervo alveolar inferior. Caso clínico: No caso, um paciente de 34 anos, branco, sexo masculino, apresentou parestesia do nervo alveolar inferior após a exodontia do terceiro molar inferior direito. Optou-se por aguardar o retorno espontâneo da sensibilidade, que ocorreu entre o primeiro e o segundo mês pós-operatório. Conclusão: O completo retorno sensitivo não ocorre em todos os casos, mesmo com os tratamentos preconizados. Portanto, a melhor maneira de lidar com a parestesia ainda é a prevenção, onde o cirurgião-dentista deve realizar o correto diagnóstico, com auxílio dos exames complementares necessários; além de possuir habilidade e destreza no manejo dos instrumentais, a fim de que a cirurgia seja realizada com segurança e sem complicações para o paciente.

Descritores: Parestesia; Remissão Espontânea; Nervo Mandibular.

\section{Resumen}

Introducción: La parestesia se caracteriza por la pérdida transitoria de la sensibilidad en el área que comprende el nervio afectado. Diferentes causas llevan a su ocurrencia como la lesión de estructuras nerviosas durante la exodoncia de terceros molares. El retorno de la sensibilidad dependerá de la regeneración de las fibras nerviosas, siendo que en la mayoría de los casos puede ocurrir espontáneamente. En algunas situaciones, hay necesidad de tratamientos más invasivos y costosos para el paciente. Objetivo: evaluar la remisión espontánea de la parestesia del nervio alveolar inferior. Caso clínico: un paciente de 34 años, blanco, sexo masculino, presentó parestesia del nervio dentario inferior tras una exodoncia del tercero molar inferior derecho. Se optó por aguardar el retorno espontáneo de la sensibilidad, lo que ocurrió entre el primer y el segundo mes postoperatorio. Conclusíon: El retorno sensitivo completo no ocurre en todos los casos, aunque con tratamientos recomendados. Así, la mejor manera de afrontar la parestesia todavía sigue siendo la prevención, cuando el cirujano dentista debe realizar el correcto diagnóstico, con auxilio de exámenes complementarios, además de poseer habilidades y destrezas en el manejo de los instrumentos a fin de que la cirugía se realice con seguridad y sin complicaciones para el paciente.

Descriptores: Parestesia; Remisión Espontánea; Nervio Mandibular.

\section{INTRODUCTION}

The extraction of third molars has become a common surgical procedure among dentists over the years. But this type of surgery may result in some accidents and complications; the most common being bleeding, alveolitis, pain, swelling, trismus, bone fractures, injuries to adjacent teeth and injury to nerve structures which includes the paresthesia of the inferior alveolar nerve $e^{1,2}$.

Paresthesia of the inferior alveolar nerve is the result of an injury to the nervous tissue caused by the proximity between the tooth and that nerve $\mathrm{e}^{3}$. The mandibular canal may present different paths, both in the upper inferior and the medial-lateral directions and may also present bitrifurcations. Moreover, there are different types of proximity relationships between the apices of the root of the third molar and the mandibular canal, which can be very close or even in contact with them. This relationship can be identified through imaging diagnosis ${ }^{4}$.

The panoramic radiography exam is very useful, but should be used with caution because of their limitations regarding bidimensionality distortions. Thus, computed tomography consists on an image with a more accurate technique that allows the correct surgical planning and minimizes post-extraction accidents. However, radiography still remains the most widely used process, due to the tomographic technique not always being possible to use, due to the difficult access, high cost and, sometimes, the need for emergency extraction ${ }^{5,6}$.

Paresthesia is characterized by unpleasant sensations, with tingling, burning, numbness and partial loss of sensitivity symptoms in the area covered by the affected 
nerve $e^{3,7,8}$.

The recovery depends on the regeneration of nerve fibers that were damaged or the regression of secondary causes that can cause this condition. Usually, paresthesia occurs transiently and patients do not need to resort to treatments, and the spontaneous sensory recovery is present in $96 \%$ of cases and occurs in up to 24 months ${ }^{2,7}$.

Within this context, this study aimed to describe the report of a case of spontaneous remission of the inferior alveolar nerve paresthesia following a third molar extraction.

\section{CASE REPORT}

Patient FJV, white, male, 34, sought the Oral Health Promotion Clinic at the School of Dentistry of Araçatuba Universidade Estadual Paulista (FOA-UNESP), complaining of severe pain at the right posterior jaw region.

Extra oral physical examination showed a normal aspect and intraoral physical examination and radiographic periapical showed there was great coronary destruction and extensive carious lesion with cavitation and pulp exposure at the tooth 48 (Figure 1). The patient was referred immediately to the Clinic of Surgery and Maxillofacial Traumatology of FOA-UNESP for the extraction of the tooth.

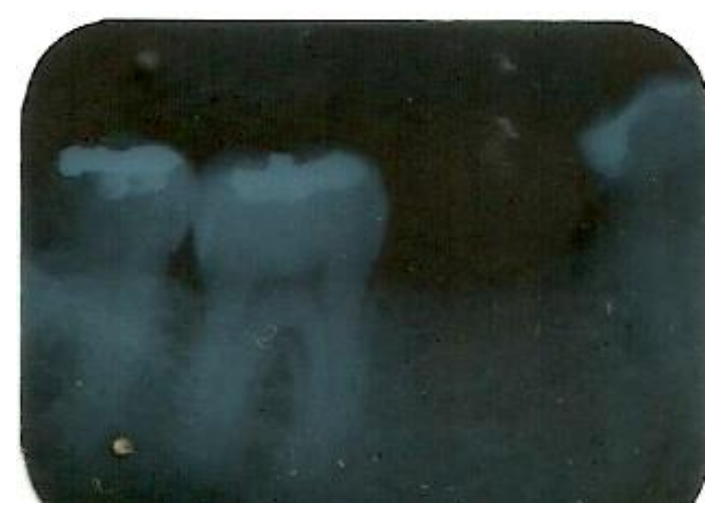

Figure 1: Periapical radiograph, where we can observe a great coronary damage and extensive carious lesion with cavitation and pulp exposure in tooth 48

Seven days after surgery, he returned to the FOAUNESP Oral Health Promotion clinic for the removal of the sutures and reported tingling sensation and absence of thermal and pain sensitivity in the oral mucosa and lip on the right. The clinical diagnosis was defined as the inferior alveolar nerve paresthesia. The patient was asked to hold a panoramic radiograph, in which it was possible to observe the alveoli of the proximity of tooth 48 to the mandibular canal (Figure 2).

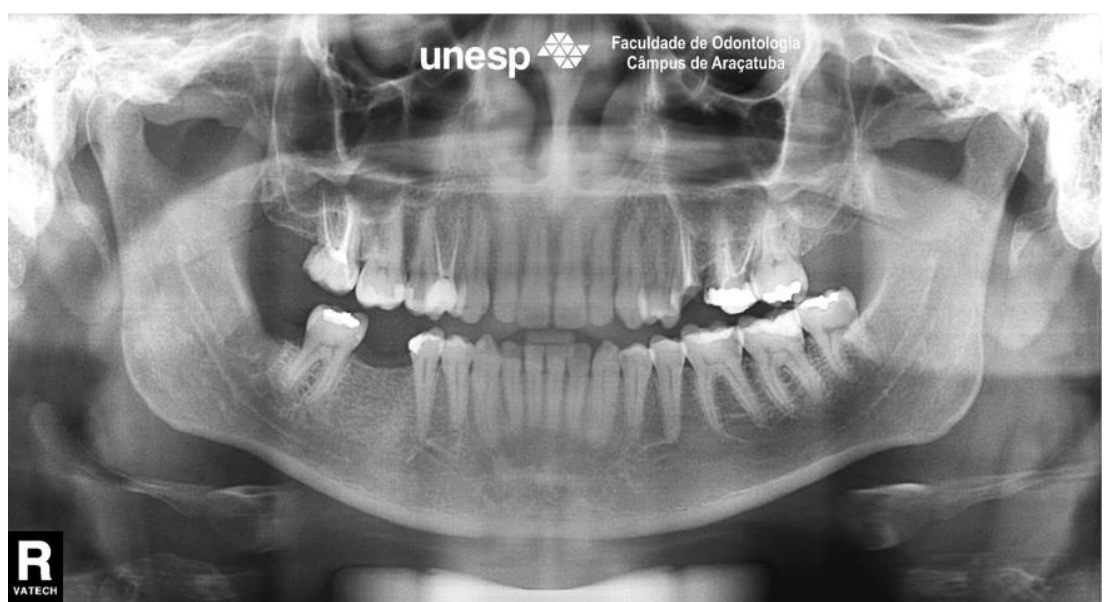

Figure 2: Panoramic radiograph, where we can observe the proximity of the alveoli in the tooth 48 with the mandibular canal.

For two months the monitoring of the case was conducted, with four periodic returns to the verification of the general conditions of the site of the dental extraction and regression feeling of paresthesia as well as the psychological management of patients. About a month after surgery, the patient reported that the tingling sensation had decreased considerably, but the absence of thermal and pain sensitivity of the labial region was still unchanged.

In his last visit, the patient reported that the sensation of paresthesia had regressed almost completely and the pain and thermal sensitivity of the labial region had practically normalized, no longer configuring as an uncomfortable condition to him.

\section{DISCUSSION}

Paresthesia is a stunning condition affecting a nerve area and can occur due to the following causes: mechanical, which has the presence of the trauma; nerve compression or stretch with full or partial rupture of nerve fibers; presence of bleeding, hematoma or edema leading to the onset of paresthesia between 24 to 48 hours after surgery ${ }^{9}$; pathological, when there is the presence of a tumor which growth causes the compression or damage to the nerve ${ }^{10}$; physical, when there is excess heat, such as caused by rotatory devices or caused by excessive cold, as in cryotherapy ${ }^{11}$; chemical, which may be caused by local anesthetic or during the use of other materials in dental procedures $^{12}$; and Microbiological that are caused by endodontic infections reaching the vicinity of the mandibular canal ${ }^{13}$.

Among the dental procedures, the most common cause for the occurrence of temporary or permanent paresthesia of the inferior alveolar nerve is the surgical removal of third molars. Its incidence varies among authors from $1.3 \%$ to $13.4 \%{ }^{14-17}$.

Currently, there was a significant increase in the number of surgical removal of third molars, a fact that can be explained by anthropology. Through evolution, man has developed jaws ever smaller in the anterior-posterior direction, and there is not enough space for the eruption of third molars in the oral cavity ${ }^{14,18}$. By analyzing the anatomy of this region we observe the close relationship between major vascular and nerve structures such as the inferior alveolar nerve; and the inferior third molars ${ }^{19}$.

The position of third molars should be carefully evaluated by the dentist to perform a correct preoperative planning, with the aid of diagnostic imaging. The panoramic radiographs exam has great use to evaluate and classify the anatomy of the mandibular canal, despite its limitations such as distortions and two-dimensionality. When this scan shows proximity between the mandibular canal and the third molar roots, one should be more cautious during the planning of the treatment to avoid injury to the inferior alveolar nerve, being this proximity considered in the literature a risk factor for the appearance of nerve injuries $^{4,6,20}$. However, computed tomography provides better and more reliable results for the diagnosis when compared to panoramic radiograph, it provides the exact location of the inferior alveolar nerve in relation to the roots of inferior third molars to be three-dimensional ${ }^{4,21}$. Because the clinical case is a dental emergency, where the patient had severe pain and mouth opening difficulty and because of the impossibility for the use of other imaging methods, we used the periapical radiography for the performance of the surgery, which prevented the observation of the proximity of the tooth roots to the mandibular canal.

It should be noted that the correct diagnosis of the case and the skill and experience of the dentist, are factors that can prevent injury to the nerve, which are caused by 
incorrect surgical planning, use of inappropriate tools, application of wrong pressure during surgery, poor visualization of the location and anxiety by the surgeon ${ }^{14,22}$.

The literature shows that when there is nerve damage and paresthesia in the region, in $96 \%$ of cases the local sensitivity is restored espontanely up to 24 months ${ }^{4}$. In some cases, when the return of the sensitivity does not occur, there is a need for a more invasive and expensive treatment to the patient such as micro neurosurgery, drug treatment (vitamin B1 or cortisone), or low - intensity laser application (GaAlAs $820 \mathrm{~nm})^{14}$. In the clinical case presented, we chose to wait for the spontaneous return of the sensitivity, because in the first postoperative month the patient has already reported improvement in the clinical symptoms of paresthesia.

\section{CONCLUSION}

It should be noted that the full sensory feedback does not occur in all cases, even with the treatments related, so the best way to deal with paresthesia is still prevention, where the dentist must perform the correct diagnosis with the aid of the necessary additional tests; along with having skills and dexterity in handling the instruments, so that the surgery to be performed safely and without complications for the patient.

\section{REFERENCES}

1. Ferreira PHSG, Oliveira D, Momesso GAC, Bonardi JP, Pastori CM, Faverani LP. Enfisema subcutâneo durante exodontias de terceiro molar: relato de caso. Arch Health Invest. 2016; 5(1):33-6.

2. Flores JA, Flores FW, Agostini RN, Cazarolli R. Parestesia do nervo alveolar inferior após a exodontia de terceiros molares inferiores inclusos. Int $\mathbf{J}$ Dent. 2011; 10(4):268-73.

3. Vaz PNC, Albuquerque P, Oliveira AIM, Loureira IM, Moreira AMS. Abordagem da medicina chinesa na parestesia do nervo alveolar inferior pós cirurgia ortognática. Rev UIIPS. 2016; 4(3):1-7.

4. Flores JA, Flores FW, Unfer MK, Ferrari R. Relação entre os terceiros molares inferiores com o nervo alveolar inferior. Int J Dent. 2009; 8(4):210-4.

5. Devito KL, Tambúrus JR. Anatomia do canal da mandíbula. Rev APCD. 2001; 55(4):261-6.

6. Florian MR, Meirelles MPMR, Sousa MLR. Uso da acupuntura em um caso de parestesiados nervos alveolar inferior e lingual. Revassocpaulcirdent. 2012; 66(4):312-5.

7. Alves FR, Coutinho MS, Gonçalves LS. EndodonticRelated Facial Paresthesia: Systematic Review. J CanDent Assoc. 2014; 80(13):1-7.

8. Kaufman A. Accessing restoration margins - a multidisciplinary approach. GenDent. 2001; 49(1):58-61.

9. Lage LG. Paralisia facial e parestesia: condutas terapêuticas, 2003 [acesso em 12 Jul 2016]. Disponível em: http: // www.cispre.com.br.

10. Masur P. Cryobiology: the freezing of biological systems. Science. 1970; 168(934):939-49.

11. Eppley BL, Snyders RV. Microanatomic analysis of the trigeminal nerve and potential nerve graft donor sites. J OralMaxillofacSurg. 1991; 49(6):612-8.

12. Morse DR. Infection-related mental and inferior alveolar nerve paresthesia: literature review and presentation of two cases. J Endod. 1997; 23(7):457-60.
13. Rosa FM, Escobar CAB, Brusco LC. Parestesia dos nervos alveolar inferior elingual pós cirurgia de terceiros molares. RGO. 2007; 55(3):291-5.

14. Bataineh AB. Sensory nerve impairment following mandibular third molar surgery. J Oral Maxillofac Surg. 2001; 59(9):1012-7.

15. Jowet NI, Cabot B. Early warning signs of impending hypoglycaemia masked by post-extraction labial paraesthesia. Br Dent J. 1998; 185(2):70-1.

16. Brann CR, Brickley MR, Shepherd JP. Factors influencing nerve damage during lower third molar surgery. Br Dent J. 1999; 186:514.

17. Lopes GB, Freitas JB. Parestesia do nervo alveolar inferior após exodontia de terceirosmolares. ArqBras Odontol. 2013; 9(2):35-40.

18. Peterson L, Ellis E, Huup J, Tucker M. cirurgia oral emaxilofacial contemporânea. 3. ed. Rio de Janeiro: Guanabara Koogan; 2000. p. 267-8.

19. Gulicher D, Gerlach KL. Incidence, risk factors and follow-up of sensation disorders after surgical wisdom tooth removal. Studyof 1,106 cases. Mund Kiefer Gesichtschir. 2000; 4(2):99-104.

20. Lazaroto C, Karpstein G, Shiroma W. Tomografia computadorizada: Vantagens sobre a radiografia panorâmica na análise de terceiros molares inferiores inclusos. Revista Dens. 2007; 15(2).

21. Damiani GJ, Céspedes IC. Prevalência de lesão dos nervosalveolar inferior, bucal e lingual emprocedimentos operatórios. Rev Odonto. 2007; 15(29):50-7.

\section{CONFLICTS OF INTERESTS}

The authors declare no conflicts of interests.

\section{CORRESPONDING AUTHOR}

Ronald Jefferson Martins

rojema@foa.unesp.br

Received 09/11/2017 Accepted 07/12/2017 